\title{
Retooling Ocean Drilling Science into Earth Science Educational Resources
}

by Leslie Peart and Ann Klaus

doi:10.2204/iodp.sd.4.10.2007

Integrating robust and relevant earth science content into higher education earth science courses is a primary objective shared by high school, undergraduate, and graduate level educators. Developing a strong educational outreach network to increase accessibility to the Integrated Ocean Drilling Program (IODP) scientific and technological accomplishments that can be used by earth science educators is a central outreach objective for the United States Implementing Organization (USIO). To marry these objectives, the Joint Oceanographic Institutions (JOI), through the USIO and the United States Science Support Program (USSSP) has created a Web portal designed specifically for K-16 educators that contains curriculum activities and background materials based on data and samples that have been generated during forty years of scientific ocean drilling.

"A central challenge for college and university educators is to create truly meaningful, thoughtful, and purposeful exercises or projects that engage our students with real data and real-world scientific problems, that expose them to the interdisciplinary scientific tools and technologies to solve problems, and that instill the sense of scientific discovery as a process involving teamwork. The rewards are clearexcitement, confidence, creativity, and retention. The educational materials posted on the JOI Learning Website provide a sampling of hands-on exercises based on scientific ocean drilling data, which can be adapted for undergraduate or graduate courses."

\section{-Dr. R. Mark Leckie, Department of Geosciences, University} of Massachusetts, U.S.A.

The JOI Learning Web site, www.joilearning.org, has achieved wide national recognition including the U.S. National Science Digital Library and the U.S. Digital Library for Earth System Education, and provides an easy-to-use portal for science educators to access content related to platform operations, drilling and engineering technology, and results from IODP, ODP (Ocean Drilling Program), and the DSDP (Deep Sea Drilling Project) scientific research expeditions. The site includes classroom activities, posters, multimedia files, career profiles, and professional development opportunities. Classroom activities can be browsed by audience (elementary, secondary, and post-secondary), content standards, or alphabetic listing. Based on the philosophy of Teaching for Science, Learning for Life ${ }^{\mathrm{TM}}$, these programs help educators to teach about Earth using

\section{Samples of Educational Tools and Activities}

at JOI Learning (www.joilearning.org)

CLASSROOM ACTIVITIES (available in Flash and PDF):

Plate Tectonics

Plate Tectonics and Contributions from Scientific Ocean Drilling: Going Back to the Original Data: Introduce your students to the original data that proved the plate tectonic theory through an examination of the original scientific data generated during DSDP Leg 3 in the South Atlantic. For Grades 9-12 and Undergraduate.

Rocks and Minerals

Core Description and Lithostratigraphy: Enter the world of a sedimentologist aboard the JOIDES Resolution as your students learn how scientists describe and sample sediment cores in the Core Lab. For Grades 9-12 and Undergraduate.

\section{Geologic Time}

How old is it? Part 1: Biostratigraphy \& Part 2: Magnetostratigraphy (Paleomagnetism) and the Geomagnetic Polarity Timescale: Let your students imagine being a micropaleontologist for a day and learn how to use microfossils to obtain ages for cores. They will learn how paleomagnetism is used to accurately date hard rock cores onboard the JOIDES Resolution. For Grades 9-12 and Undergraduate.

Climate Change

Abrupt Events of the Past 70 Million Years: Evidence from Scientific Ocean Drilling: Analyze evidence of climate change and use the data to provide evidence for abrupt climate changes at critical times in Earth's history. For Grades 9-12 and Undergraduate.

High Resolution Marine Ice Core and Marine Sediment Records: Archives of Orbital Oscillations (Milankovitch Cyclicity) in Climate: Discover Milankovitch cycles as your class unravels the data that define climate cycles that are controlled by the orbit of the Earth. For Grades 9-12 and Undergraduate.

Paleomagnetism

A Rocky Timescale 1: Help your students understand how a paleomagnetic record is recorded in rocks and deciphered by scientists through this exercise where they measure and record declination in model cores. For Grades 5-8 and 9-12.

Geophysics

Why Did They Drill There?: Let your students imagine being a scientist writing a proposal to carry out scientific ocean drilling. This activity guides students through the drill site location decision-making process. For Grades 9-12 and Undergraduate.

Engineering

A "Bit" of Engineering: This new twist on an old earth science coring activity provides an opportunity to look at ocean drilling through the eyes of the driller and the engineer by testing three different drilling tools on a variety of ocean bottom substrates. For Grades 5-8.

Chemistry

All Caged Up: This inquiry-based activity on methane hydrates allows students to model two clathrate structures commonly found in methane hydrates, challenging them to learn about gas laws, hydrogen bonding, and chemical formation. For Grades 5-12. (continued on next page $\rightarrow$ ) 
education disciplines from chemistry, physics, biology, and math to engineering and technology to reading and writing. The JOI Learning materials and curricular activities are generated through collaborations with scientists that have extensive research and teaching experience in fields related to ocean drilling science, classroom and museum science educators with academic backgrounds in geology, and JOI Learning staff.

Materials have been generated through programs such as the School of Rock Expedition, which utilized the drilling platform JOIDES Resolution as a science and educational learning laboratory for informal and formal educators for (see Scientific Drilling No. 3, September 2006, page 62, for a description of the expedition). The educators working with experienced scientists on previously recovered deep sea cores and published data from fifty-six drill sites greatly increased their knowledge about ocean drilling and created new ways to communicate ocean drilling science results to target audiences. (See Table 1.)

Over the course of the past year, participants in this program have developed ten new college-level activities, fifteen pre-college activities, twenty career profiles, nine instructional laboratory demonstration videos, and one instructional poster (see sidebar) that are available on the JOI Learning Web site. Professional development related to the program was also conducted at local, regional, and national levels, disseminating information about JOI Learning resources to K-16 earth science educators. Thus far, thirty outreach events have been conducted, ranging from short talks and presentations to posters at scientific conferences, a short course at GSA, workshops at science education conferences, and a 5-day graduate course for teachers at Western Michigan University. Early evaluations suggest the School of Rock Expedition program could impact as many as 300,000 US students over the next five years. This program will serve as a template for future educator-focused expeditions aboard the IODP-USIO Phase 2 riserless drilling vessel

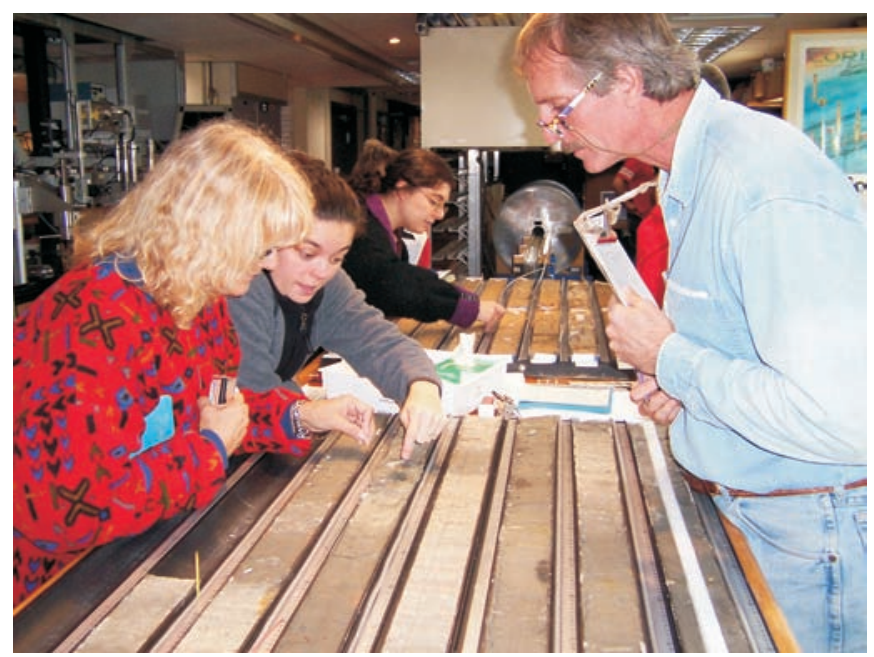

Figure 1. Educators describe core on the JOIDES Resolution during the School of Rock Expedition.
Don't Try This at Home: Follow the fun as a teacher journals her experiences teaching about methane hydrates. This activity helps teachers foster a class-wide discussion to form a question and hypothesis and to design an experiment to discover what methane hydrates are and how they relate to the gas laws. For Grades 9-12.

Geography

It's a Small World After All: Let students test their geographic and cultural knowledge as they learn about the great diversity of people living and working aboard the JOIDES Resolution. For Grades K-12.

POSTERS:

A Bolt from the Blue: This poster illustrates the chemical formation of gas-bearing ice-like structures deep below the world's oceans and outlines the structure and sources of methane hydrates, introducing fundamentals for advanced chemistry and/or Earth system science courses.

Microfossils: The Ocean's Storytellers: Use this poster and related activities to simulate the identification and use of microfossils to examine past climate change. Poster features microphotographs from DSDP and ODP cores.

MULTIMEDIA:

History of Our Planet Revealed: Stories Only Rocks Can Tell: Which technology and the scientific techniques are used to read the history of the Earth from ocean floor sediments and rocks? How are scientists using the holes we have drilled in the seafloor to measure active processes that are controlling our planet today? A lecture presented by Dr. Paul J. Fox, Director, IODP-USIO Science Services, TAMU, to the National Congress for Science Education in August 2005.

Underwater Re-entry: Scientists frequently want to re-enter boreholes that were drilled during an expedition. This short video shows the drill string latching onto a re-entry cone during an ODP Leg.

Tripping Pipe: Watch the process of "tripping pipe" (the term used for the connecting or disconnecting 30 meter sections of drill pipe) in action on the JOIDES Resolution.

Shipboard Laboratory Briefs: Explore the unique scientific laboratories onboard the JOIDES Resolution and learn about the instruments used in each laboratory, the types of measurements made, and how the data are used by scientists to study Earth's history.

School of Rock Expedition: The School of Rock Expedition Web site links undergraduate and precollege activities with a wealth of supplemental resources. Check out the Q\&A section for questions and answers about shipboard research and scientific ocean drilling in written and video form; the "Where in the World?" section for an online interactive about latitude and longitude; and "High S.E.A. Adventures with Mr. Buchholtz" videotaped lessons and demonstrations from the labs on board the JOIDES Resolution.

Career Profiles: Through an interactive photo mosaic that depicts the JOIDES Resolution, download or access 20 one-page career profiles that highlight some of the diverse careers available in the IODP program.

\section{FUTURE PROFESSIONAL DEVELOPMENT OPPORTUNITIES:}

Future professional development opportunities will include more science and curriculum development programs for teachers and faculty either via sailing on the JOIDES Resolution through the "Teacher at Sea" and "School of Rock" programs; or at the IODP core repositories, conferences, or other university laboratory settings. Scientists interested in participating in these programs as faculty should contact Leslie Peart (Director, Education, Ipeart@joiscience.org). 
Table 1. Connecting scientific themes with ocean drilling data

\begin{tabular}{|c|c|}
\hline Topic & DSDP, ODP, IODP Data from Leg/Expedition \\
\hline Plate Tectonics - Paradigm Overview & DSDP 3 \\
\hline $\begin{array}{l}\text { Marine Sediments - Lithostratigraphy } \\
\text { Drilling, receiving and describing sediment core }\end{array}$ & ODP 130, 145, 204, 206; IODP 303 \\
\hline $\begin{array}{l}\text { Microfossils - Biostratigraphy } \\
\text { Describing marine sediments and sampling sediment core }\end{array}$ & ODP 130, 145, 198, 202, 204, 206; IODP 303 \\
\hline $\begin{array}{l}\text { Paleomagnetism - Magnetostratigraphy } \\
\text { Earth's magnetic field } \\
\text { Geomagnetic Polarity Time Scale (GPTS) }\end{array}$ & ODP 198, 199, 202 \\
\hline $\begin{array}{l}\text { Geohydrology - Introduction to CORKS } \\
\text { Monitoring fluid flow at spreading centers }\end{array}$ & IODP 301 \\
\hline $\begin{array}{l}\text { Geophysics - Seismic Stratigraphy } \\
\text { Site selection } \\
\text { Sea level change }\end{array}$ & ODP 149, 150, 173, 174A, 208 \\
\hline $\begin{array}{l}\text { Carbonate Geochemistry } \\
\text { Carbonate analysis }\end{array}$ & ODP 130, 145, 206 \\
\hline $\begin{array}{l}\text { Ocean Crust } \\
\text { Drilling curating describing basement core }\end{array}$ & ODP 206 \\
\hline $\begin{array}{l}\text { Abrupt Events - Deep Time Examples } \\
\text { Cretaceous/Paleogene (K/P) boundary } \\
\text { Paleocene/Eocene Thermal Maximum (PETM) } \\
\text { Eocene/Oligocene (E/O) boundary interval }\end{array}$ & ODP 171B, 189, 198, 199, 207, 208 \\
\hline $\begin{array}{l}\text { Climate Cyclicity } \\
\text { Milankovitch (orbital) cycles } \\
\text { Suborbital cycles (Heinrich events, Dansgaard-Oeschger } \\
\text { oscillations) }\end{array}$ & DSDP 94; ODP 108, 143B, 154, 162, 165, 177, 198, 199 \\
\hline $\begin{array}{l}\text { Post-cruise Research Example } \\
\text { Reconstructing paleoclimate }\end{array}$ & ODP 152 \\
\hline
\end{tabular}

Notes: See Leckie, et al. (2006) for specific site and hole resources from these ocean drilling legs/expeditions. Access these data via http://www.iodp. org/access-data/.

as well as for hands-on programs held at the IODP-USIO repository and other university laboratory settings.

Other ocean drilling-related curricular activities on the JOI Learning site have been developed by teachers participating in the USIO's Teacher at Sea Program. Through this program, middle and high school teachers are invited to participate in full expeditions where they work side-by-side with the expedition scientists and are required to produce educational content related to the program that will be added to the JOI Learning library. Examples of teacher-generated products include Laboratory Briefs that describe the function of each shipboard lab (http://www.joilearning.org/classroom/lab_briefs.html) and the Expedition 309 poster, "The 'Hole' Story about Ocean Cores (http://www.joilearning. org/images/309_poster_lg.jpg)."

Much of the content of the JOI Learning resources are appropriate for higher education audiences, and soon a portal specifically designed for this audience will be added to the site and continue to be expanded during Phase 2 of IODP. These activities are available for international use by anyone who is interested in using them. We encourage undergraduate and graduate educators to drill down into the resources on the JOI Learning site and integrate them into earth science courses. We also invite educators to contact JOI Learning if you are interested in contributing undergraduate or graduate activities or work with the JOI Learning staff on future ocean drilling science education programs.

\section{Authors}

Ann Klaus, Deputy Director of Data Services, Integrated Ocean Drilling Program, United States Implementing Organization, Texas A\&M University, 1000 Discovery Drive, College Station, Texas 77845-9547, U.S.A., e-mail: annklaus@ iodp.tamu.edu.

Leslie Peart, Director, Education, Joint Oceanographic Institutions, 1201 New York Avenue, NW, Suite 400, Washington, DC 20005, U.S.A.

\section{Reference}

Leckie, R.M., St. John, K., Peart, L., Klaus, A., Slough, S., Niemitz, M., 2006. Education and science connect at sea. Eos, Trans. Am. Geophys. Union, 87(24):240. doi:10.1029/2006EO240003

\section{Web Link}

www.joilearning.org 